\title{
Sediminicola luteus gen. nov., sp. nov., a novel member of the family Flavobacteriaceae
}

Correspondence

Shams Tabrez Khan

shams-tabrez-khan@nite.go.jp

\author{
Shams Tabrez Khan, Yasuyoshi Nakagawa and Shigeaki Harayama \\ Biological Resource Center (NBRC), National Institute of Technology and Evaluation (NITE), \\ 2-5-8, Kazusakamatari, Kisarazu, Chiba 292-0818, Japan
}

\begin{abstract}
The taxonomic position of four Gram-negative, rod-shaped, golden-yellow-coloured bacteria isolated from marine sediments was determined. Analysis of the almost complete 16S rRNA gene sequences indicated that these isolates belong to the family Flavobacteriaceae. An unclassified bacterium, NBRC 15975, was found to be the closest relative, showing $16 S$ rRNA gene sequence similarity of $93 \%$; other related genera shared only $87 \cdot 9-90 \cdot 5 \%$ similarity. In contrast, the four isolates shared high levels of $16 \mathrm{~S}$ rRNA gene sequence similarity (99.3-99.7\%) and high DNA-DNA reassociation values (93-104\%). The isolates could be differentiated phenotypically from other genera by the abilities to reduce nitrate and to degrade gelatin, casein and starch. The only respiratory quinone was MK- 6 , and the major fatty acids were iso- $C_{15: 0}$, iso- $C_{15: 1}$, anteiso- $\mathrm{C}_{15: 0}$, iso- $\mathrm{C}_{17: 1} \omega 9 \mathrm{C}$ and iso- $\mathrm{C}_{17: 0} 3-\mathrm{OH}$. The DNA G+C content was $38-40 \mathrm{~mol} \%$. Differentiating phenotypic characteristics and large phylogenetic distances between the isolates and previously published genera indicated that the isolates constitute a novel genus, for which the name Sediminicola gen. nov. is proposed. The type species is Sediminicola luteus sp. nov. (type strain $\mathrm{CNI}-3^{\top}=$ NBRC $100966^{\top}=$ LMG $23246^{\top}$ ).
\end{abstract}

The family Flavobacteriaceae, proposed 20 years ago (Jooste, 1985), is one of the fastest growing families: more than half of the genera have been established during the last 3 years. Members of this family are widely distributed in diverse habitats (Bernardet et al., 2002), including marine environments [e.g. the genera Aquimarina, Gramella, Polaribacter, Psychroflexus and Gelidibacter (Bernardet et al., 2002; Nedashkovskaya et al., 2005a, b)] in which they may be numerically dominant (Glöckner et al., 1999).

In this study, we report the isolation and characterization of four novel strains from sediments collected on the shores of the Pacific Ocean and the Sea of Japan. On the basis of phylogenetic analyses of these strains, a novel genus of the family Flavobacteriaceae, Sediminicola gen. nov., is proposed.

Strains CNI-3 ${ }^{\mathrm{T}}\left(=\mathrm{NBRC} 100966^{\mathrm{T}}=\mathrm{LMG} 23246^{\mathrm{T}}\right)$, CNI-1-5 (=NBRC 100968) and MNI-85 (=NBRC 100969) were isolated from sediments at Nigata on the shore of the Sea of Japan, whereas strain PMAOS-27 (=NBRC 100967) was isolated at Odawara on the shore of the Pacific Ocean. For routine cultivation and maintenance, marine agar 2216 (MA; Difco) at $20^{\circ} \mathrm{C}$ was used; $20 \%(\mathrm{v} / \mathrm{v})$ glycerol in artificial sea water at $-80{ }^{\circ} \mathrm{C}$ was used for long-term preservation. Cultures grown for 3 days on MA were used to observe colony shape and colour. Cells grown on MA were observed

The GenBank/EMBL/DDBJ accession numbers for the 16S rRNA gene sequences of strains $\mathrm{CNI}-1-5, \mathrm{CNI}-3^{\top}$, MNI-85 and PMAOS-27 are AB206956, AB206957, AB206958 and AB206959, respectively. under a light microscope equipped with a digital camera (CX41LF; Olympus). Gliding motility was observed by using the hanging drop method (Perry, 1973) under a $\times 1000$ oilimmersion objective. LB medium $[2 \mathrm{~g}$ Bacto tryptone (Difco) and $1 \mathrm{~g}$ Bacto yeast extract (Difco) in $1000 \mathrm{ml}$ water] supplemented with $1,3,5,7$ or $10 \%(\mathrm{w} / \mathrm{v}) \mathrm{NaCl}$ or with $10,30,50$ or $70 \%(\mathrm{v} / \mathrm{v})$ artificial sea water (Naigai Chemicals) was used to test the ability of the bacteria to grow at different salt concentrations. Tolerance of high salt concentrations was also tested in marine broth 2216 (MB; Difco) with a final $\mathrm{NaCl}$ concentration adjusted to 5,8 or $10 \%$. Growth at $4,10,20,30,37,40$ and $45^{\circ} \mathrm{C}$ was assessed on MA and in LBM (LB prepared with artificial sea water). The bathochromic shift test of McCammon \& Bowman (2000) was performed to check for the presence of flexirubin-type pigments. For the detection of carotenoid pigments, absorption spectra of acetone extracts from 3-day-old cultures were analysed using a Shimadzu UVvisible spectrophotometer (UV-1650 PC). The production of catalase was assessed by flooding the cultures on agar plates with $3 \%(\mathrm{v} / \mathrm{v}) \mathrm{H}_{2} \mathrm{O}_{2}$. Cells suspended in water were spotted onto a cytochrome oxidase strip (Nissui Pharmaceuticals), and a change in colour from white to blue was taken as a positive result for the production of oxidase. The degradation of agar and carrageenan (Type I; Sigma) was assessed on MB solidified with $1.5 \%(\mathrm{w} / \mathrm{v})$ of each polymer, while hydrolysis of carboxymethylcellulose (high viscosity; Sigma) was tested on MB solidified with $3 \%(\mathrm{w} / \mathrm{v})$ carboxymethylcellulose sodium salt. The degradation of 
crystalline cellulose was assessed by cultivating the bacteria in 1/5-strength LBM medium containing Whatman (No. 1) paper strips at $20^{\circ} \mathrm{C}$ for 1 month. The oxidation of different carbon sources was tested using Biolog GN2 Microplates (Biolog) according to Rüger \& Krambeck (1994). The Sherlock Microbial Identification System (MIDI) was used for fatty acid methyl ester analysis. Isoprenoid quinones were extracted and analysed by using the method of Nakagawa \& Yamasato (1993). Nitrate reduction, indole production from typtophan, acid production from glucose and hydrolysis of urea, aesculin and gelatin were tested using API 20 NE strips (bioMérieux) according to the instructions of the supplier, except that inocula were prepared in artificial sea water. The degradation of starch, chitin, casein, gelatin and DNA was assessed by using the protocols of Cowan \& Steel (1993). The 16S rRNA gene was amplified by using the set of universal primers 27f and 1492r (Brosius et al., 1978), and a DNA template prepared by using InstaGene matrix (Bio-Rad). PCR products purified using a QIAquick ${ }^{\circledR}$ (Qiagen) kit were sequenced using an ABI BigDye Terminator v1.1 Cycle Sequencing kit and an ABI PRISM 3100 genetic analyser (Applied Biosystems). Sequences were edited and assembled using the ATGC program (Genetyx) and were compared with 16S rRNA gene sequences from public databases by using the BLAST program (Altschul et al., 1990). Related sequences were aligned using the CLUSTAL X program (Thompson et al., 1997). A phylogenetic tree was inferred using the neighbourjoining method (Saitou \& Nei, 1987) and the topology was evaluated by using a bootstrap resampling analysis of 1000 replicates (Felsenstein, 1985). DNA was extracted from cells grown to late exponential growth phase by using the protocol of Minamisawa (1990). The fluorometric hybridization method of Ezaki et al. (1989) was used to determine the DNA-DNA reassociation values at a hybridization temperature of $50{ }^{\circ} \mathrm{C}$ in $25 \%$ formamide. The DNA G $+\mathrm{C}$ content was determined using the HPLC method of Mesbah et al. (1989).

The almost complete 16S rRNA gene sequences (1440 bp) of the isolates showed the highest level of similarity (93\%) with an unclassified bacterium, NBRC 15957. Other valid genera in the family Flavobacteriaceae shared rather low levels of sequence similarity $(87 \cdot 9-90 \cdot 5 \%)$ with the isolates. In contrast, the novel isolates had high levels of $16 \mathrm{~S}$ rRNA gene

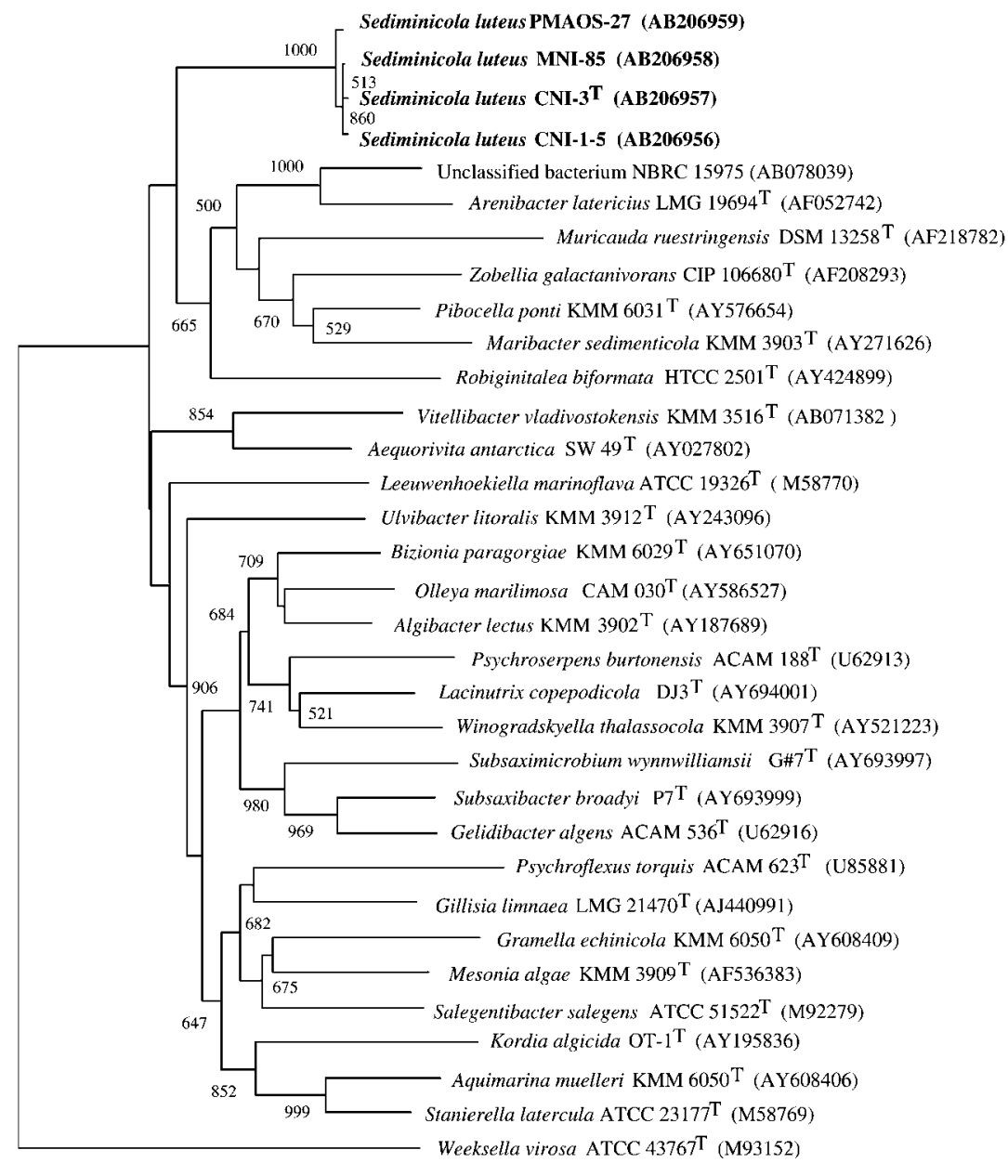

0.02
Fig. 1. Rooted tree, based on $16 \mathrm{~S}$ rRNA gene sequences, showing the position of the novel isolates in the family Flavobacteriaceae. The tree was generated by using the neighbour-joining method (Saitou \& Nei, 1987); bootstrap values indicated at branches were calculated from 1000 resamplings (Felsenstein, 1985). Values below 500 are not shown. Bar, $0.02 K_{\text {nuc }}$. Weeksella virosa was used as an outgroup. 
sequence similarity $(99 \cdot 3-99 \cdot 7 \%)$ and high DNA-DNA reassociation values (93-104\%) with each other. Phylogenetic analysis of the 16S rRNA gene sequences revealed that the four isolates formed a distinct lineage within the family Flavobacteriaceae (Fig. 1). These data suggest that the novel monophyletic clade constitutes a novel genus in the family Flavobacteriaceae.

The phenotypic and biochemical features of the isolates are given in the genus and species descriptions and in Table 1. The following fatty acids were detected in all of the strains (percentage values in the type strain CNI- $3^{\mathrm{T}}$ are shown in parentheses, and fatty acids amounting to less than $1 \%$ are not listed): $\mathrm{i}-\mathrm{C}_{15: 0}(12 \%), \mathrm{i}-\mathrm{C}_{17: 0} 3-\mathrm{OH}(12 \%), \mathrm{a}-\mathrm{C}_{15: 0}$ $(11 \%), \mathrm{i}-\mathrm{C}_{15: 1}(11 \%)$, summed feature $3\left(\mathrm{C}_{16: 1} \omega 7 c / \mathrm{i}-\mathrm{C}_{15: 0}\right.$ $2-\mathrm{OH})(14 \%), \mathrm{i}-\mathrm{C}_{17: 1} \omega 9 c(9 \%), \mathrm{i}-\mathrm{C}_{16: 0}(5 \%), \mathrm{i}-\mathrm{C}_{16: 0}$ $3-\mathrm{OH}(5 \%), \mathrm{i}-\mathrm{C}_{16: 1}(3 \%), \mathrm{i}-\mathrm{C}_{15: 0} 3-\mathrm{OH}(4 \%)$ and $\mathrm{i}-\mathrm{C}_{14: 0}$ (1\%). Pentadecanoic acid $\left(\mathrm{C}_{15: 0}\right)$ was absent from all of the novel strains, but present in all the related genera shown in Table 1 . The DNA G $+\mathrm{C}$ contents of the four strains were in the range $38-40 \mathrm{~mol} \%$.

The strains differed from other Flavobacteriaceae genera with validly published names in terms of a number of features listed in Table 1. On the basis of the results of $16 \mathrm{~S}$ rRNA gene analysis and the differences in phenotypic characteristics, we propose that these strains should be classified as a novel genus of the family, for which the name Sediminicola gen. nov. is proposed; the type species is Sediminicola luteus sp. nov.

\section{Description of Sediminicola gen. nov.}

Sediminicola [se.di.mi.ni.co'la. L. n. sedimen -inis sediment; L. masc. suff. - cola (from L. n. incola) an inhabitant; N.L. masc. $n$. Sediminicola an inhabitant of sediment, referring to the source of the strains].

Gram-negative, aerobic, rod-shaped, non-motile cells. Produces golden-yellow-coloured carotenoid pigments. Flexirubin-type pigments are not produced. Predominant cellular fatty acids are $\mathrm{i}-\mathrm{C}_{15: 0}, \mathrm{a}-\mathrm{C}_{15: 0}, \mathrm{i}-\mathrm{C}_{15: 1}, \mathrm{i}-\mathrm{C}_{17: 1} \omega 9 \mathrm{c}$, $\mathrm{i}-\mathrm{C}_{17: 0} 3-\mathrm{OH}$ and summed feature $3\left(\mathrm{C}_{16: 1} \omega 7 \mathrm{c} / \mathrm{i}-\mathrm{C}_{15: 0}\right.$ $2-\mathrm{OH})$. Sequence analysis of $16 \mathrm{~S}$ rRNA genes shows that Sediminicola is a member of the family Flavobacteriaceae. The DNA G $+\mathrm{C}$ content of the type species is in the range $38-40 \mathrm{~mol} \%$. The type species is Sediminicola luteus.

\section{Description of Sediminicola luteus sp. nov.}

Sediminicola luteus (lu.te'us. L. masc. adj. luteus golden yellow, because the colony colour is golden yellow).

In addition to possessing the characteristics given in the description of the genus, the cells are $0 \cdot 5-0 \cdot 7 \mu \mathrm{m}$ in width and 3-5 $\mu \mathrm{m}$ in length; 7-day-old cells form longer filaments of 5-10 $\mu \mathrm{m}$. Growth occurs at $10-30{ }^{\circ} \mathrm{C}$; the optimal growth temperature is $20^{\circ} \mathrm{C}$. Growth occurs in $10-100 \%$ strength artificial sea water. $\mathrm{NaCl}$ alone is not sufficient to support growth. Positive for catalase and weakly positive for oxidase. Positive for degradation of gelatin, casein and starch and for nitrate reduction. Urea, chitin, cellulose, CM-cellulose

Table 1. Differentiating phenotypic characteristics for the novel isolates and other related genera

Genera: 1, Sediminicola gen. nov. (this study); 2, Robiginitalea (Cho \& Giovannoni, 2004); 3, Arenibacter (Nedashkovskaya et al., 2004a); 4, Muricauda (Yoon et al., 2005); 5, Vitellibacter (Nedashkovskaya et al., 2003); 6, Maribacter (Nedashkovskaya et al., 2004b); 7, Zobellia (Nedashkovskaya et al., 2004c); 8, Pibocella (Nedashkovskaya et al., 2005c); 9, Ulvibacter (Nedashkovskaya et al., 2004d). Abbreviations: Y, yellow; O, orange; $\mathrm{Y}-\mathrm{O}$, yellow to orange; ND, not determined; +, positive; -, negative; w, weak; v, variable.

\begin{tabular}{|c|c|c|c|c|c|c|c|c|c|}
\hline Characteristics & 1 & 2 & 3 & 4 & 5 & 6 & 7 & 8 & 9 \\
\hline Gliding motility & - & - & - & - & - & + & + & + & - \\
\hline \multicolumn{10}{|l|}{ Hydrolysis of: } \\
\hline Gelatin & + & - & $\mathrm{V}$ & - & + & $\mathrm{V}$ & + & + & + \\
\hline Casein & + & - & - & - & + & - & $\mathrm{V}$ & + & - \\
\hline Starch & + & + & - & - & - & $\mathrm{V}$ & $\mathrm{V}$ & + & - \\
\hline Urease activity & - & - & $\mathrm{V}$ & - & - & - & - & - & - \\
\hline Nitrate reduction & + & - & + & - & - & $\mathrm{V}$ & + & - & + \\
\hline \multicolumn{10}{|l|}{ Growth with/at: } \\
\hline $8 \sim 10 \% \mathrm{NaCl}$ & - & + & $\mathrm{V}$ & + & - & - & $\mathrm{V}$ & + & - \\
\hline DNA G $+\mathrm{C}$ content $(\mathrm{mol} \%)$ & $38-40$ & $55-56$ & $37-40$ & $41-45$ & 41 & $35-39$ & $36-43$ & 35 & $36-38$ \\
\hline
\end{tabular}


and DNA are not depolymerized. Indole is not produced from tryptophan. Acid is not produced from glucose. $\alpha$-Cyclodextrin, dextrin, glycogen, cellobiose, D-fructose, D-galactose, gentiobiose, $\alpha$-D-glucose, $\alpha$-D-lactose, lactulose, maltose, D-mannitol, D-mannose, D-melibiose, methyl $\beta$-Dglucoside, raffinose, sucrose, trehalose, turanose, DL-lactic acid, L-aspartic acid, L-glutamic acid, glycyl L-aspartic acid, glycyl L-glutamic acid, L-ornithine, L-proline, L-threonine and glucose 1-phosphate are oxidized. Tweens 40 and 80, Nacetyl-D-galactosamine, $\mathrm{N}$-acetyl D-glucosamine, adonitol, D-arabitol, i-erythritol, L-fucose, myo-inositol, L-rhamnose, D-sorbitol, xylitol, methyl pyruvic acid, mono-methyl succinic acid, acetic acid, cis-aconitic acid, citric acid, formic acid, D-galactonic acid lactone, D-galacturonic acid, D-gluconic acid, D-glucosaminic acid, D-glucuronic acid, $\alpha$-, $\beta$ - and $\gamma$-hydroxybutyric acid, $p$-hydroxyphenylacetic acid, itaconic acid, $\alpha$-ketoglutaric acid, $\alpha$-ketovaleric acid, malonic acid, propionic acid, quinic acid, D-saccharic acid, sebacic acid, succinic acid, bromosuccinic acid, succinamic acid, glucuronamide, alaninamide, D-alanine, L-alanine, L-alanyl glycine, L-asparagine, L-histidine, hydroxy-L-leucine, L-phenylalanine, L-pyroglutamic acid, D-serine, L-serine, DL-carnitine, $\gamma$-aminobutyric acid, inosine, thymidine, phenylethylamine, putrescine, 2-aminoethanol, 2,3-butanediol, glycerol, DL- $\alpha$-glycerol phosphate and glucose 6-phosphate are not oxidized. The DNA G $+\mathrm{C}$ content of the type strain is $38 \mathrm{~mol} \%$.

The type strain, CNI- $3^{\mathrm{T}}\left(=\mathrm{NBRC} 100966^{\mathrm{T}}=\mathrm{LMG} 23246^{\mathrm{T}}\right)$, was isolated from marine sediment on the shore of the Sea of Japan.

\section{Acknowledgements}

This work was supported by the New Energy Development Organization (NEDO).

\section{References}

Altschul, S. F., Gish, W., Miller, W., Myers, E. W. \& Lipman, D. J. (1990). Basic local alignment search tool. J Mol Biol 215, 403-410.

Bernardet, J.-F., Nakagawa, Y. \& Holmes, B. (2002). Proposed minimal standards for describing new taxa of the family Flavobacteriaceae and emended description of the family. Int J Syst Evol Microbiol 52, 1049-1070.

Brosius, J., Palmer, M. L., Kennedy, P. J. \& Noller, H. F. (1978). Complete nucleotide sequence of a $16 \mathrm{~S}$ ribosomal RNA gene from Escherichia coli. Proc Natl Acad Sci U S A 75, 4801-4805.

Cho, J.-C. \& Giovannoni, S. J. (2004). Robiginitalea biformata gen. nov., sp. nov., a novel marine bacterium in the family Flavobacteriaceae with a higher $\mathrm{G}+\mathrm{C}$ content. Int J Syst Evol Microbiol 54, 1101-1106.

Cowan, S. T. \& Steel, K. J. (1993). Manual for the Identification of Medical Bacteria, 3rd edn. London: Cambridge University Press.

Ezaki, T., Hashimoto, Y. \& Yabuuchi, E. (1989). Fluorometric deoxyribonucleic acid-deoxyribonucleic acid hybridization in microdilution wells as an alternative to membrane filter hybridization in which radioisotopes are used to determine genetic relatedness among bacterial strains. Int J Syst Bacteriol 39, 224-229.
Felsenstein, J. (1985). Confidence limits on phylogenies: an approach using the bootstrap. Evolution 39, 783-791.

Glöckner, F. O., Fuchs, B. M. \& Amann, R. (1999). Bacterio-plankton compositions of lakes and oceans: a first comparison based on fluorescence in situ hybridization. Appl Environ Microbiol 65, 3721-3726.

Jooste, P. J. (1985). The taxonomy and significance of FlavobacteriumCytophaga strains from dairy sources. $\mathrm{PhD}$ thesis, University of the Orange Free State, South Africa.

McCammon, S. A. \& Bowman, J. P. (2000). Taxonomy of Antarctic Flavobacterium species: description of Flavobacterium gillisiae sp. nov., Flavobacterium tegetincola sp. nov., and Flavobacterium xanthum sp. nov., nom. rev. and reclassification of [Flavobacterium] salegens as Salegentibacter salegens gen. nov., comb. nov. Int J Syst Evol Microbiol 50, 1055-1063.

Mesbah, M., Premachandran, U. \& Whitman, W. B. (1989). Precise measurement of the $\mathrm{G}+\mathrm{C}$ content of deoxyribonucleic acid by high-performance liquid chromatography. Int J Syst Bacteriol 39, 159-167.

Minamisawa, K. (1990). Division of rhizobitoxine-producing and hydrogen-uptake positive strains of Bradyrhizobium japonicum by nifDKE sequence divergence. Plant Cell Physiol 31, 81-89.

Nakagawa, Y. \& Yamasato, K. (1993). Phylogenetic diversity of the genus Cytophaga revealed by $16 \mathrm{~S}$ rRNA sequencing and menaquinone analysis. J Gen Microbiol 139, 1155-1161.

Nedashkovskaya, O. I., Suzuki, M., Vysotskii, M. V. \& Mikhailov, V. V. (2003). Vitellibacter vladivostokensis gen. nov., sp. nov., a new member of the phylum Cytophaga-Flavobacterium-Bacteroides. Int J Syst Evol Microbiol 53, 1281-1286.

Nedashkovskaya, O. I., Kim, S. B., Han, S. K., Lysenko, M., Mikhailov, V. V. \& Bae, S. K. (2004a). Arenibacter certesii sp. nov., a novel marine bacterium isolated from the green alga Ulva fenestrata. Int J Syst Evol Microbiol 54, 1173-1176.

Nedashkovskaya, O. I., Kim, S. B., Han, S. K. \& 7 other authors (2004b). Maribacter gen. nov., a new member of the family Flavobacteriaceae, isolated from marine habitats, containing the species Maribacter sedimenticola sp. nov., Maribacter aquivivus sp. nov., Maribacter orientalis sp. nov. and Maribacter ulvicola sp. nov. Int J Syst Evol Microbiol 54, 1017-1023.

Nedashkovskaya, O. I., Suzuki, M., Vancanneyt, M., Cleenwerck, I., Lysenko, A. M., Mikhailov, V. V. \& Swings, J. (2004c). Zobellia amurskyensis sp. nov., Zobellia laminariae sp. nov. and Zobellia russellii sp. nov., novel marine bacteria of the family Flavobacteriaceae. Int J Syst Evol Microbiol 54, 1643-1648.

Nedashkovskaya, O. I., Kim, S. B., Han, S. K., Rhee, M. S., Lysenko, A. M., Falsen, E., Frolova, G. M., Mikhailov, V. V. \& Bae, S. K. (2004d). Ulvibacter litoralis gen. nov., sp. nov., a novel member of the family Flavobacteriaceae isolated from the green alga Ulva fenestrata. Int J Syst Evol Microbiol 54, 119-123.

Nedashkovskaya, O. I., Kim, S. B., Lysenko, A. M., Frolova, G. M., Mikhailov, V. V., Lee, K. H. \& Bae, S. K. (2005a). Description of Aquimarina muelleri gen. nov., sp. nov., and proposal of the reclassification of [Cytophaga] latercula Lewin 1969 as Stanierella latercula gen. nov., comb. nov. Int J Syst Evol Microbiol 55, 225-229.

Nedashkovskaya, O. I., Kim, S. B., Lysenko, A. M., Frolova, G. M., Mikhailov, V. V., Bae, S. K., Lee, D. H. \& Kim, I. S. (2005b). Gramella echinicola gen. nov., sp. nov., a novel halophilic bacterium of the family Flavobacteriaceae isolated from the sea urchin Strongylocentrotus intermedius. Int J Syst Evol Microbiol 55, 391-394.

Nedashkovskaya, O. I., Kim, S. B., Lee, K. H., Bae, S. K., Frolova, G. M., Mikhailov, V. V. \& Kim, I. S. (2005c). Pibocella ponti gen. nov., sp. nov., a novel marine bacterium of the family Flavobacteriaceae 
isolated from the green alga Acrosiphonia sonderi. Int J Syst Evol Microbiol 55, 177-181.

Perry, L. B. (1973). Gliding motility in some non-spreading flexibacteria. J Appl Bacteriol 36, 227-232.

Rüger, H.-J. \& Krambeck, H.-J. (1994). Evaluation of the BIOLOG substrate metabolism system for classification of marine bacteria. Syst Appl Microbiol 17, 281-288.

Saitou, N. \& Nei, M. (1987). The neighbor-joining method: a new method for reconstructing phylogenetic trees. Mol Biol Evol 4, 406-425.
Thompson, J. D., Gibson, T. J., Plewniak, F., Jeanmougin, F. \& Higgins, D. G. (1997). The CLUSTAL_X windows interface: flexible strategies for multiple sequence alignment aided by quality analysis tools. Nucleic Acids Res 25, 4876-4882.

Yoon, H.-J., Li, M.-H., Oh, T.-K. \& Park, Y.-H. (2005). Muricauda flavescens sp. nov. and Muricauda aquimarina sp. nov., isolated from a salt lake near Hwajinpo Beach of the East Sea in Korea, and emended description of the genus Muricauda. Int J Syst Evol Microbiol 55, 1015-1019. 